\title{
The Impact of Human and Computer Interaction on eLearning Quality
}

\author{
https://doi.org/10.3991/ijim.v16i04.27309 \\ Farhan Alebeisat $^{1(\bowtie)}$, Haroon Altarawneh ${ }^{2}$, Zaid T. Alhalhouli ${ }^{1}$, Ali Qatawneh ${ }^{1}$, \\ Mohmmad Almahasne ${ }^{1}$ \\ 'Tafila Technical University, Tafila, Jordan \\ ${ }^{2}$ Al-Balqa Applied University, Alkarak, Jordan \\ fobisat@ttu.edu.jo
}

\begin{abstract}
Over the last few years, particularly during the COVID-19 pandemic, the education ways have shifted from face-to-face learning to hybrid, blinding learning and fully online learning Human-Computer Interaction (HCI) has facilitated the development of alternative and advanced ways to implement the concept of e-learning by providing all the means that attract teachers and students to use these means by providing integrated educational content that everyone can easily access from anywhere and at any time. The research aims to measure the impact of $\mathrm{HCI}$ on the quality of e-learning from the point of view of the teacher and the student by measuring several factors, namely: impact of HCI on the quality of (1) teachers, (2) LMSs, and (3) learning content. To achieve the goal of the research, the researchers designed a questionnaire and used Google tools as a means of communicating with students from the target group at Tafila Technical University (TTU) to answer the questionnaire questions remotely. The data were analyzed using the SPSS program, and it was concluded that the respondents' opinion about the effect of HCI on the quality of e-learning is positive and has an impact on all the factors described previously.
\end{abstract}

Keywords-human computer interaction, HCI, e-learning, e-learning quality, content quality

\section{Introduction}

The concept of Human-Computer Interaction (HCI) is critical in clarifying the term data management using objects, Smart devices, and intelligently connected devices to computer networks and the internet. It also has a significant effect in demonstrating the mechanism of interaction between network components and other virtual components and physical objects, as well as connecting them to users and learners. The term "e-learning" refers to the process of integrating information and communication technology into the educational environment with the goal of improving learning and training. The term "e-learning" is frequently used to refer to a variety of different forms of digital learning, including online and virtual education. By converting educational resources and processes to a digital format, it enables more flexible methods of enhancing learning across various departments and employees in educational 
institutions. Using the HCI process hypothetical products, the educational process can be implemented and tracked.

Employing interaction in education is a boon, particularly in the last decade and now during the Covid-19 pandemic, because it has enabled the development of both the educational process and the infrastructure of educational institutions by providing platforms and tools resulting from the information revolution. However, this opportunity is fraught with difficulties, as embodied in multiple axes such as safety, capability, and human resistance, there are numerous country-specific aspects at influence.

The quality of e-learning is related to the criteria for effective learning, the delivery method for content related to teaching methodologies, and evaluation implementation. Numerous aspects influence the quality of information systems, including data correctness, simplicity of use, user perception, system features and functionalities, system integrity, reaction time, and completion time. Relevance, utility, information richness, and readability are all indicators of information quality. Consistency, comprehensiveness, and freshness of information are also indicators of information quality. Software developers and engineers rely on Software Quality criteria as a vital component of design [1].

Educational platforms such as Thuraya leverage e-books, research programs, and interactive courses to provide a variety of planned and systematic educational situations that aid in developing experience and productivity when it comes to implementing innovative technology in education.

Most Jordanian universities have made significant investments in teaching systems and technology, allowing faculty members to add educational programs to subjects while utilizing online educational platforms (Al Thuraya, Microsoft Team, and Moodle) hosted on the university's web servers to provide students with a variety of resources.

In this era, the development of E-learning management systems is rapid, and its purpose is to provide the educational institutions with tools to serve as a point of contact between teachers and students and to provide multiple educational resources that serve the educational process at various levels. One of the most important elements of software success is its acceptance by users and their interaction with it, and this depends on the software quality. So, the purpose of this work is to investigate the impact of human-computer interaction (HCI) on the quality of e-learning during the Covid-19 epidemic.

The rest of the paper is organized as follows: First, an overview of the related works; Second, the research methodology, which includes the study's test community, questionnaire design, and data collection; Third, the analysis and result discussion section, which contains sufficient results to make the reader conscious of the impact of HCI on the quality of e-learning; Fourth, the Conclusion. Finally, the future works and limitation.

\section{Related work}

This section of the paper reviews previous studies regarding E-learning Platforms and tools, software quality from different perspectives and reviews the results of these studies regarding the impact of Human-Computer Interaction (HCI) on the enhancement of software quality.

E-learning contributes to the proper flow of knowledge within educational institutions [2]. E-learning supported learning processes by providing a suite of innovative 
services to students, employees, managers, trainers, and educational institutions. Numerous firms, including Canvas, Blackboard, and Moodle, have embraced it [3].

Giannakos [4] examined controlled e-learning systems, such as those that make advantage of social media environments. Yuan [5] investigated the function of trainers and managers in facilitating knowledge exchange through the establishment of units to arrange educational materials and the provision of communication channels such as chatting and video sharing.

Hammad [6] investigated the development of maturity models, such as (eLCMM), an e-learning capability maturity model that addresses technology problems. E-learning was defined as the use of Internet technologies to give a variety of solutions for improving knowledge and performance. Through the use of computer and communication technologies, improves and enhances learning [7].

The components of e-learning include the presentation of content in a variety of formats, the management of the learning experience and the learners' network community, as well as the role of content developers and specialists. It defines e-learning as a personalized method that is centered on the learner and incorporates self-coaching, various virtual events, mentoring, simulation, and evaluation, as well as a competency roadmap [8].

One study distinguished between formal and non-formal education and distinguished between digital education, mobile education, and e-learning, examining the differences, similarities, advantages, and disadvantages of e-learning, mobile learning, and digital learning, as well as the terminology used in e-learning, mobile learning, and digital learning [9].

Teachers and students use digital technology to create interactive educational resources [10]. To facilitate interactions between humans and artificial cognition, a collection of insights is presented on how to integrate and expand human cognitive capabilities with those of surrounding digital technologies. The possibilities for developing $\mathrm{HCI}$ are numerous and can be used to a variety of domains, including control systems, image analysis, touch interfaces, motion control, and auditory control, from which certain conclusions were formed [11].

There is a positive correlation between the quality of information, the quality of education systems, and the content of user happiness. Service quality is a criterion for an e-learning system's effectiveness, and it is quantified through responsiveness, compassion, trust, and security [12].

Higher education policy places a premium on increasing the use of ICTs for teaching, learning, and inter-university communication to alleviate strain on universities' limited available resources. To improve the efficiency and quality of teaching and learning, one of the most critical priorities is to provide universities with high-quality communication and e-learning services [13].

To maintain a high standard of education, the process of developing software products that aid graduate students in accomplishing needed activities must be examined [14].

Universities have made e-learning a strategic priority, providing different resources to assist front-line staff in incorporating innovative teaching methods and technology into their teaching and learning processes. Universities are accountable for the educational quality of their programs [15].

Numerous national organizations and bodies have produced a variety of standards and frameworks for describing and evaluating the quality of e-learning. It is difficult to quantify in universities because to the range of courses and teaching curricula, particularly in the realm of e-learning [16]. 
Poultsakis et al. in 2021 [21] specified that the technological equipment is the main reason for the negative attitude for using the Digital Learning Objects (DLOs) or Digital Simulation Tools (DSTs) between the teachers in the Primary and Secondary schools. The teachers' situation comes from the shortage of training, teaching experience, the number of students, and the negative trust in courses contents. A descriptive study was conducted by Karakose et al. in 2021 [22] to determined the relationships between the COVID-19 phobia experienced by school administrators and their work-family conflict, family-work conflict, and life satisfaction. A positive relationship appeared, and the Females and the younger age group are affected with COVID-19 phobia more than their male peers, although the female group is more satisfied than males.

A bibliometric research study was conducted to analyze the management, leadership, and administration-oriented publications related to COVID-19. As a result, most of the publications are concentrated in the field of health. Additionally, Anglo-American-, Chinese-, and European-centered dominance continues in COVID-19-related studies. Most of these publications were published in a short time and were in English and the most prestigious journals [23].

In summary, by reviewing previous studies, that e-learning contributed to the correct flow of knowledge, so researchers focused on identifying weaknesses and ways of displaying content and determining the differences between e-learning and traditional education. Additionally, the importance of e-learning has been proven to raise and facilitate interactions between humans and modern technology tools, which in turn provided ideas for the development of human-computer interaction (HCI) to deal with these modern systems, and it has been proven that the happiness of the human user of these systems is related to the quality of information, content, and service provided. There were many views regarding e-learning and the universities began to work hard to develop e-learning instructions and policies to be compatible with e-learning technology, so it was necessary to study the general policies of traditional education and the ability to use them in e-learning. Studies prove that work on developing e-learning tools is still in its infancy and should not stop due to its connection to technology and human-computer interaction tools.

\section{$3 \quad \mathrm{HCI}$ in e-learning}

HCI has a great role in designing effective solutions within the concept of E-learning with a primary focus on ease of use.

Educational institutions have developed a variety of teaching methodologies and skill development approaches to generate graduates who are masters of the educational material delivered in novel ways and utilizing new technology principles [17]. Now, $\mathrm{HCI}$ is having a significant impact on education by delivering cutting-edge tools and appropriate technology as e-learning materials. Through the application of HCI assessment approaches, educational technology tools and platforms can be developed and evaluated to create a highly productive environment, particularly for learners. The first stage is for students to engage actively in educational technology tools to investigate various aspects of human-computer interaction ( $\mathrm{HCI}$ ) in the educational system.

E-learning requires solutions that integrate a library of interactive user interface designs (UI). Applications suitable for various user levels that adhere to HCI principles, particularly for basic users that can be considered at the school level, the user interface 
design can contain the appropriate user interface screen on This level is concerned with typography, color, and graphics [18]. Designers should conduct extensive research into the potential of human-computer interaction (HCI) in e-learning and pedagogical education to enhance the user's natural learning experience; this will aid in the creation of a successful e-learning environment in comparison to the traditional environment.

To enhance the educational process, the e-learning system must be user-friendly and accessible to all potential users [19]. Numerous things must be addressed when developing a customized system. Numerous researches have relied on the GOMS model (Goals, Operators, Methods, and Selection) to determine evaluation variables. This approach is based on cognitive psychology.

Table 1. Set of HCI assessment indicators for the e-learning system [20]

\begin{tabular}{|l|c|l|}
\hline \multicolumn{1}{|c|}{ Level 1 Index Set } & No & \multicolumn{1}{c|}{ Level 2 Index Set } \\
\hline \multirow{4}{*}{ Cognitive Effect } & 1 & Find ability of information \\
\cline { 2 - 3 } & 2 & Recognize ability of information \\
\cline { 2 - 3 } & 3 & Information matching cognitive type of user \\
\cline { 2 - 3 } Organization Structure & 4 & Information interactivity reaction \\
\hline & 5 & Organizational structure is clear and reasonable \\
\cline { 2 - 3 } & 6 & Whether there is a reasonable link \\
\cline { 2 - 3 } Interaction & 7 & Link type and the reasonableness of set \\
\hline & 8 & The consistency of the of information \\
\hline & 9 & Reasonable interactive test \\
\cline { 2 - 3 } & 10 & After-class training and comment \\
\cline { 2 - 3 } & 11 & Assessment and analyses of intelligence \\
\hline
\end{tabular}

\section{$4 \quad$ Research methodology}

The researchers did a systematic review of Related Literature in order to better understand the idea of e-learning quality. The study incorporated a variety of keywords, including human-computer interaction, e-learning, educational Internet platforms, digital education, mobile-based education, and e-learning quality. Additionally, the researchers provided a list of synonyms that convey implications about the impact of human connection on e-learning to facilitate users' access to information about success factors and barriers to e-learning. A tailored set of criteria has been developed to assist in recognizing these effects on students, including program design and interface, usability, and student effectiveness in determining the quality of e-learning.

In this research, a questionnaire was designed to examine the impact of HCI on the quality of teachers (Assurance, Empathy, Reliability, and Responsiveness), the quality of learning management systems (LMSs) (Informativeness, Usability), and lastly the quality of learning content in Jordanian institutions.

To check the correctness of the questionnaire items, a pilot study was conducted, in which a total of 50 questionnaires were distributed by hand to students of the target group in the research from Tafila Technical University students. Only 42 questionnaires were retrieved. The researchers found that the students needed an average of 13 minutes 
to finish answering the questionnaire; this result is within the recommendations of Chua (2010) [24]. On the other hand, a reliability test was conducted for all the questionnaire items and separately for each measure; the result was that the assays met the recommended Cronbach's alpha and are reliable [25].

After validating the questionnaire through the pilot study, a google link was sent to the target group which is the scientific majors (Information Technology and software engineering) at Jordan's Tafila Technical University (TTU), and the link has been activated for a week.

\subsection{Survey design}

The questionnaire was designed with great accuracy based on previous studies and was divided into two separate groups: demographic Information (personal Information); and the measurement factors group, as shown in Tables 2 and 3. The questionnaire was constructed using the Likert scale, a psychological measure that is frequently used in questionnaire-based research. Respondents indicate their level of agreement or disagreement with a sequence of questions using a comparable scale (agree/disagree). In this paper, a normal five-level Likert element format (Strongly Disagree, Disagree, Neutral, Agree, and Strongly Agree) is utilized (Strongly Disagree, Disagree, Neutral, Agree, and Strongly Agree).

The measurement factors group is divided into three sections: the first section is concerned with teacher quality, the second with learning management system (LMS) quality, and the third with learning content quality. The questionnaire contains questions that students must answer to assess their understanding of the impact of human-computer interaction on e-learning quality.

Table 2. Personal information

\begin{tabular}{|c|c|}
\hline \multicolumn{2}{|l|}{ Personal Information } \\
\hline \multirow{2}{*}{ Gender } & Male \\
\hline & Female \\
\hline \multirow{4}{*}{ Student Rank } & 4th Year \\
\hline & 3rd Year \\
\hline & 2nd Year \\
\hline & 1st Year \\
\hline \multirow{2}{*}{ Scientific Major } & IT department \\
\hline & Software engineer \\
\hline \multirow{2}{*}{ 1. HCI has a positive impact ship on teacher quality } & Yes \\
\hline & No \\
\hline \multirow{2}{*}{ 2. HCI has a positive impact Leaning management system quality } & Yes \\
\hline & No \\
\hline \multirow{2}{*}{ 3. HCI has a positive impact on Learning content quality } & Yes \\
\hline & No \\
\hline
\end{tabular}


Table 3. Measurement factors

\begin{tabular}{|c|c|c|c|c|c|c|}
\hline $\begin{array}{l}\text { Domain of } \\
\text { the Item }\end{array}$ & Survey Items & $\begin{array}{l}\text { Agree } \\
\text { Strongly }\end{array}$ & Agree & Neutral & Disagree & $\begin{array}{l}\text { Disagree } \\
\text { Strongly }\end{array}$ \\
\hline \multirow[t]{6}{*}{$\begin{array}{l}\text { Impact of } \\
\text { HCI on } \\
\text { Teacher } \\
\text { Quality }\end{array}$} & $\begin{array}{l}\text { 1. The presence of classroom } \\
\text { discussions such as chatting } \\
\text { characterizes the e-learning } \\
\text { process }\end{array}$ & & & & & \\
\hline & $\begin{array}{l}\text { 2. learning process has } \\
\text { reliability and has good } \\
\text { interactivity }\end{array}$ & & & & & \\
\hline & $\begin{array}{l}\text { 3. Available documents, related } \\
\text { training courses and other } \\
\text { information can be shared } \\
\text { and downloaded }\end{array}$ & & & & & \\
\hline & $\begin{array}{l}\text { 4. Feedback can easily be } \\
\text { provided }\end{array}$ & & & & & \\
\hline & $\begin{array}{l}\text { 5. Ease of completing the tasks } \\
\text { required of me }\end{array}$ & & & & & \\
\hline & $\begin{array}{l}\text { 6. Attention and solutions can } \\
\text { be obtained in the event } \\
\text { that problems arise in the } \\
\text { e-learning process }\end{array}$ & & & & & \\
\hline \multirow{6}{*}{$\begin{array}{l}\text { Impact of } \\
\text { HCI on } \\
\text { Learning } \\
\text { management } \\
\text { system } \\
\text { (LMS) } \\
\text { quality }\end{array}$} & $\begin{array}{l}\text { 7. I feel confident using the } \\
\text { e-learning system }\end{array}$ & & & & & \\
\hline & $\begin{array}{l}\text { 8. The quality of information } \\
\text { positively affects the } \\
\text { e-learning process }\end{array}$ & & & & & \\
\hline & $\begin{array}{l}\text { 9. The learning process at the } \\
\text { e-learning platform gives } \\
\text { us flexibility to navigate in } \\
\text { learning resources }\end{array}$ & & & & & \\
\hline & $\begin{array}{l}\text { 10. The learning process at the } \\
\text { e-learning platform is clear } \\
\text { and structured }\end{array}$ & & & & & \\
\hline & $\begin{array}{l}\text { 11. The course content in } \\
\text { the system is available in } \\
\text { multimedia form }\end{array}$ & & & & & \\
\hline & $\begin{array}{l}\text { 12. The content and information } \\
\text { available in the e-learning } \\
\text { system is organized }\end{array}$ & & & & & \\
\hline
\end{tabular}

(Continued) 
Table 3. Measurement factors (Continued)

\begin{tabular}{|c|c|c|c|c|c|c|}
\hline $\begin{array}{l}\text { Domain of } \\
\text { the Item }\end{array}$ & Survey Items & $\begin{array}{c}\text { Agree } \\
\text { Strongly }\end{array}$ & Agree & Neutral & Disagree & $\begin{array}{l}\text { Disagree } \\
\text { Strongly }\end{array}$ \\
\hline \multirow{3}{*}{$\begin{array}{l}\text { Impact of } \\
\text { HCI on } \\
\text { Learning } \\
\text { content } \\
\text { quality }\end{array}$} & $\begin{array}{l}\text { 13. The content and information } \\
\text { available in the e-learning } \\
\text { system is very useful }\end{array}$ & & & & & \\
\hline & $\begin{array}{l}\text { 14. Content and information } \\
\text { available in the e-learning } \\
\text { system is easy to understand. }\end{array}$ & & & & & \\
\hline & $\begin{array}{l}\text { 15. The visual and design of } \\
\text { the learning resources in } \\
\text { the learning process is } \\
\text { acceptable }\end{array}$ & & & & & \\
\hline
\end{tabular}

\subsection{Data collection}

This investigation employed the survey method. The data was gathered via a Google Forum questionnaire. The questionnaire was distributed to a random sample of students studying computer technology and software engineering at Tafila Technical University. The following Table 4 shows the respondent's percentage of the survey according to the demographic information.

Table 4. Statistical information

\begin{tabular}{|c|c|c|c|}
\hline \multicolumn{2}{|c|}{ Gender } & \multicolumn{2}{c|}{ Academic Year } \\
\hline \multirow{2}{*}{ Male } & \multirow{2}{*}{$71.7 \%$} & $1 \mathrm{st}$ & $28.3 \%$ \\
\cline { 3 - 4 } & & $2 \mathrm{nd}$ & $23.9 \%$ \\
\hline \multirow{2}{*}{ Female } & \multirow{2}{*}{$28.3 \%$} & $3 \mathrm{rd}$ & $23.9 \%$ \\
\cline { 3 - 4 } & & 4 th & $23.9 \%$ \\
\hline
\end{tabular}

All questions were completed and assessed using Google Questioner and SPSS software, as the relevant questionnaires can be performed easily and quickly online. SPSS was used for static analysis, consistency analysis, and regression analysis.

\section{$5 \quad$ Analysis and result discussion}

The questionnaire dealt with several factors that study the impact of HCI on the quality of e-learning. The paper used the SPSS tools to analyze the target group answers.

After analyzing the collected data, the researchers found that all the groups were confirmed, and the $\mathrm{P}>0.05$ of each item in each group. Also, the reliability test results approved that all the scales met the required Cronbach's alpha $(>=0.70)$ [24], as shown in Table 5. 
Table 5. Reliability testing of the measurement scales for the quality

\begin{tabular}{|l|c|c|}
\hline \multicolumn{1}{|c|}{ Groups } & Number of Items & Cronbach's Alpha \\
\hline Impact of HCI on Teacher Quality & 6 & 0.927 \\
\hline $\begin{array}{l}\text { Impact of HCI on Learning management } \\
\text { system (LMS) quality }\end{array}$ & 6 & 0.916 \\
\hline Impact of HCI on Learning content quality & 3 & 0.931 \\
\hline
\end{tabular}

The first factor discusses the impact of HCI on teacher quality. The results indicate that the students surveyed have varying perspectives on the impact of HCI on the quality of teachers in the e-learning process and on the usefulness for learning and teaching. The result demonstrates unequivocally that the great majority of learners have a favorable opinion of HCI in terms of teacher quality and understand the concept of e-learning. The study revealed a widespread agreement with the activation of classroom discussions, teachers' capacity to exchange and download pertinent documents, and teachers' ability to gain attention and resolutions when issues arise during e-learning. As it was found that $64 \%$ of the respondents agree that HCI has a positive effect on the quality rate, while the percentage of rejection and strong rejection reached $30 \%$, which is somewhat low, and the rest are neutral. This indicates that HCI has a significant and beneficial influence on teacher quality. The result unequivocally shows that the vast majority of learners have a positive opinion of $\mathrm{HCI}$ in terms of teacher quality and understanding of the e-learning concept.

The second factor studying the existence of the impact of HCI on the quality of the learning management system (LMS). The survey's findings indicated that HCI has a positive effect on the quality of the LMS, which included feelings of confidence when using the e-learning system, the flexibility of e-learning platforms, and their role in organizing academic content, administering tests and Providing multimedia tools. The results of the analysis show that $54 \%$ agree, while $22 \%$ disagree.

The third factor discusses the positive impact of HCI on learning content quality. The results related to the quality of educational content also indicated a positive effect of HCI on educational content from the students' point of view in terms of ease of comprehension and usefulness of the content, as well as the role of visual design in the communication and information exchange process in an intuitive way. A $55 \%$ of students felt that there was a favorable effect, whereas $25 \%$ disagreed.

Thus, the concept of HCI has a beneficial effect on the quality of the e-learning process, particularly for university students, because it provides multiple options that keep pace with current technological development and address emerging issues such as the Covid-19, limiting their impact on the learning process's continuity and providing alternatives to address them.

The results of the study agree with the results of previous studies such as [13],[14],[15], [21], and [22], where the researchers should work on developing eLearning systems and take advantage of the features offered by the HCI to facilitate the use of these systems and attract the educational institutions to adopt it as an essential educational tool. 


\section{Conclusion}

One of the methods used to ensure quality in e-learning concepts is to adhere to the basic principles of human-computer interaction (HCI) and improve interfaces such as educational platforms, e-learning websites, and e-learning applications. Also, e-learning applications provide appropriate assessment methods such as multiple-choice questions and text questions and provide appropriate exercises and assignments for students. This method of learning is highly adaptable to the student's preferred learning styles, is highly structured, and uses an attractive visual design of the learning resources. The results show that using the ICT for learning enables the students to solve more learning issues and supports the development of technologies that support e-learning. In addition, motivating students to use computers at home or school, introducing them the benefits of using the internet technology for downloading the learning documents, using search engines to find the learning materials, and using email addresses to share the knowledge and receive last news about new learning methods, all of that help students and teachers to improve the effectiveness of their learning and teaching.

\section{$7 \quad$ Future works and limitations}

The study measures the impact of human-computer interaction (HCI) on eLearning quality, but it does not suggest any methods to enhance the quality and how to activate the use of the HCI in the future. On the other hand, quality is a complex topic with many dimensions, and therefore there is an opportunity for researchers to expand the study of the topic from other aspects that have not been studied here.

The researchers had difficulty expanding the study sample due to the existence of laws and regulations that prevent entry to non-employees in educational institutions to prevent the spread of the COVID-19, so we advise researchers to study a larger sample to reach broader and comprehensive results.

\section{References}

[1] Al Obisat, F. M., Alhalhouli, Z. T., Alrawashdeh, T. I., \& Alshabatat, T. E. (2018). Review of literature on software quality. World of Computer Science and Information Technology Journal, 8(5), 32-42.

[2] Menolli, A., Tirone, H., Reinehr, S., \& Malucelli, A. (2020). Identifying organisational learning needs: an approach to the semi-automatic creation of course structures for software companies. Behaviour \& Information Technology, 39(11), 1140-1155. https://doi.org/10. 1080/0144929X.2019.1653372

[3] Garavan, T. N., Heneghan, S., O’Brien, F., Gubbins, C., Lai, Y., Carbery, R., ... \& Grant, K. (2019). L\&D professionals in organisations: much ambition, unfilled promise. European Journal of Training and Development, 44(1), 1-86. https://doi.org/10.1108/EJTD09-2019-0166

[4] Giannakos, M. N., Mikalef, P., \& Pappas, I. O. (2021). Systematic literature review of e-learning capabilities to enhance organizational learning. Information Systems Frontiers, 1-17. https://doi.org/10.1007/s10796-020-10097-2 
[5] Yuan, B., Wang, M., Kushniruk, A. W., \& Peng, J. (2017). Deep learning towards expertise development in a visualization-based learning environment. Journal of Educational Technology \& Society, 20(4), 233-246.

[6] Hammad, R., Odeh, M., \& Khan, Z. (2017, January). ELCMM: an e-learning capability maturity model. In Proceedings of the 15th International Conference (e-Society 2017) (pp. 169-178).

[7] Wentling, T. L., Waight, C., Gallaher, J. et al. (2000). E-learning: A review of literature. In Knowledge and Learning Systems Group. USA: University of Illions at Urbana-Champaign, pp. 1-73.

[8] Gowda, R. S., \& Suma, V. (2017, February). A comparative analysis of traditional education system vs. e-Learning. In 2017 International Conference on Innovative Mechanisms for Industry Applications (ICIMIA) (pp. 567-571). IEEE. https://doi.org/10.1109/ ICIMIA.2017.7975524

[9] Basak, S. K., Wotto, M., \& Belanger, P. (2018). E-learning, m-learning and d-learning: conceptual definition and comparative analysis. E-Learning and Digital Media, 15(4), 191-216. https://doi.org/10.1177/2042753018785180

[10] Borba, M. C., de Souza Chiari, A. S., \& de Almeida, H. R. F. L. (2018). Interactions in virtual learning environments: new roles for digital technology. Educational Studies in Mathematics, 98(3), 269-286. https://doi.org/10.1007/s10649-018-9812-9

[11] Katona, J. (2021). A review of human-computer interaction and virtual reality research fields in cognitive InfoCommunications. Applied Sciences, 11(6), 2646. https://doi.org/10.3390/ app11062646

[12] Seta, H. B., Hidayanto, A. N., \& Abidin, Z. (2020). Variables affecting e-learning services quality in Indonesian higher education: students' perspectives. Journal of Information Technology Education, 19, 259-286. https://doi.org/10.28945/4489

[13] Atoum, A., Al-Zoubi, A., Jaber, M. A., Al-Dmour, M., \& Hammad, B. (2017). A new approach for delivering eLearning courses in Jordanian universities. Advances in Social Sciences Research Journal, 4(8). https://doi.org/10.14738/assrj.48.3071

[14] Zlatarov, P., Ivanova, G., Ibryamova, E., \& Baeva, D. The 14th International Scientific Conference eLearning and Software for Education Bucharest, April 19-20, 2018.

[15] Yeung, C. L., Zhou, L., \& Armatas, C. (2019, November). An overview of benchmarks regarding quality assurance for eLearning in higher education. In 2019 IEEE Conference on e-Learning, e-Management \& e-Services (IC3e) (pp. 1-6). IEEE. https://doi.org/10.1109/ IC3e47558.2019.8971808

[16] Oliver, R. (2005). Quality assurance and e-learning: blue skies and pragmatism. Research in Learning Technology, 13(3), 173-187. https://doi.org/10.3402/rlt.v13i3.10996

[17] Nassuora, A. B. (2012). Students acceptance of mobile learning for higher education in Saudi Arabia. American Academic \& Scholarly Research Journal, 4(2), 24-30.

[18] Likert, R. (1932). A technique for the measurement of attitudes. Archives of Psychology, $140,1-55$.

[19] Alameri, J., Masadeh, R., Hamadallah, E., Ismail, H. B., \& Fakhouri, H. N. (2020). Students' Perceptions of E-learning platforms (Moodle, Microsoft Teams and Zoom platforms) in The University of Jordan Education and its Relation to self-study and Academic Achievement During COVID-19 pandemic. Advanced Research and Studies Journal, 11(5), 21-33.

[20] Granić, A., \& Ćukušić, M. (2007, July). Universal design within the context of e-learning. In International Conference on Universal Access in Human-Computer Interaction (pp. 617-626). Springer, Berlin, Heidelberg. https://doi.org/10.1007/978-3-540-73283-9 68

[21] Poultsakis, S., Papadakis, S., Kalogiannakis, M., \& Psycharis, S. (2021). The management of digital learning objects of natural sciences and digital experiment simulation tools by teachers. Advances in Mobile Learning Educational Research, 1(2), 58-71. https://doi. org/10.25082/AMLER.2021.02.002 
[22] Karakose, T., Yirci, R., \& Papadakis, S. (2021). Exploring the interrelationship between COVID-19 phobia, work-family conflict, family-work conflict, and life satisfaction among school administrators for advancing sustainable management. Sustainability, 13(15), 8654. https://doi.org/10.3390/su13158654

[23] Karakose, T., Yirci, R., Papadakis, S., Ozdemir, T. Y., Demirkol, M., \& Polat, H. (2021). Science mapping of the global knowledge base on management, leadership, and administration related to COVID-19 for promoting the sustainability of scientific research. Sustainability, 13(17), 9631. https://doi.org/10.3390/su13179631

[24] Yu, T. K., Lu, L. C., \& Liu, T. F. (2010). Exploring factors that influence knowledge sharing behavior via weblogs. Computers in Human Behavior, 26(1), 32-41. https://doi. org/10.1016/j.chb.2009.08.002

[25] Hair, J. F., Black, W. C., Babin, B. J., \& Anderson, R. E. (2010). Canonical correlation: A supplement to multivariate data analysis. Multivariate data analysis: a global perspective. 7th edn. Pearson Prentice Hall Publishing, Upper Saddle River.

\section{Authors}

Dr. Farhan Alebeisat is currently an Associate Prof. Working in Tafila Technical University (TTU) in the Department of Information Technology since 2012 College of ICT. His research interests are Information Systems, E-technology, web application, and Software Engineering. I carried out my Ph.D. degree in 2009, and I have published many papers in different areas. Email: fobisat@ttu.edu.jo

Dr. Haroon Altarawneh is an Associate Prof. at Al-Balqa Applied University, Jordan. His principal research interests are software ware engineering, eLearning Systems, and artificial intelligence. Email: Dr.haroon@bau.edu.jo

Dr. Zaid Alhalhouli is an assistant professor at the Information Technology Department, College of ICT, Tafila Technical University from 2015 till now. He was awarded a Ph.D. in ICT from Tenaga National University (UNITEN), Malaysia at the beginning of 2015. His research fields include E-learning systems, mobile computing technology, big data, machine learning, information and knowledge sharing, Information technology and healthcare, Social Networks, and human-computer interaction. He is a member and more coordinated in many international and national projects. Email: zaid halhouli@,ttu.edu.jo

Ali Qatawneh is a master's student at Tafila University, specializing in CyberPhysical Systems. Email: aliqatawneh300@gmail.com

Mohmmad Almahasne is a master's student at Tafila University, specializing in Cyber-Physical Systems. Email: Mohmmadalmhasni@gmail.com

Article submitted 2021-10-05. Resubmitted 2021-12-04. Final acceptance 2021-12-06. Final version published as submitted by the authors. 